\title{
AUTOMATIC TRANSFER SWITCH PANEL IN PLN ELECTRICITY AND POWER INVERTER 2000 WATT
}

\author{
Rony Haendra Rahwanto Fora*, Sunandar \\ Department of Electrical Engineering \\ University of PGRI Adi Buana Surabaya \\ *Corresponding email address: ronifora@yahoo.co.id
}

\begin{abstract}
In line with the development of science and technology today, especially in the field of electricity brought many changes in the use of electricity. Electricity is currently needed both industrial and non-industrial. Electricity needs are currently provided by PLN as the main power source. The flow of electricity from the electricity grid is not always continuous in its distribution, one day there must be a blackout that may be caused by interference with the transmission system or distribution system. To anticipate this outage, it is necessary to design an automatic control called an automatic transfer switch and to prepare a backup source, a 2000-watt power inverter. Automatic transfer switch is electrical equipment that functions as a controller of the process of switching the PLN electricity supply to the inverter power supply or vice versa automatically. In the operation of this automatic transfer switch can be operated manually and automatically. Where is in automatic mode, if there is a power outage on PLN this tool is useful for turning on and connecting the power inverter to the load automatically. When PLN revives, this tool will transfer the power source to the load from the power inverter to the PLN electricity. At this time technological advances are developing very rapidly, technology is an inspiration so that life in the world becomes lighter, easier and practical.
\end{abstract}

Keywords: automatic control, automatic transfer switch, power inverter.

\section{INTRODUCTION}

In line with the development of science and technology today, especially in the electricity sector brought many changes in the use of electricity. Electricity has a very important role in today's electricity needs absolutely needed by both industry and non-industry. Because every piece of equipment that contains high technology uses mostly electricity as a power source. Indirectly, it can be said that without electricity, all kinds of high technology will be useless. So that the existence of electricity greatly affects the mobility of modern life [1], [2]. In general, people obtain electricity from the state electricity company, if in Indonesia it is PLN, so the use of electricity depends on the electricity supply from PLN. As the main power source, it is not possible to supply electricity continuously without a disconnection. This is because the PLN itself continues to make improvements to the power generation system, transmission to the distribution network, so that at any time it requires a power cut in several network locations [3] [4].

Thus, if consumers rely solely on electricity supply from PLN alone, it can be ensured that the continuous supply of electric power cannot be fulfilled, therefore a backup power plant is needed as an alternative if the source from PLN experiences a disruption or interruption in this case the electricity source the backup used is a 2000watt power inverter [5], [6].

The control system is now beginning to shift to the automation of the control system, so that human intervention in control is very small [7], [8]. When compared with manual workmanship, the equipment system that is controlled by automation will provide benefits in terms of efficiency, safety, and accuracy [9], [10]. Can be understood based on the meaning of the word, the automatic transfer switch is a switch that works automatically, but the automatic work is based on the possibility that if the source of electricity from the PLN is cut off or experiencing a blackout then the switch will switch to another power source, for example a 2000-Watt power inverter. 


\section{RESEARCH METHODS}

The method used is the design method that is making automatic transfer switch panels on PLN electricity and 2000-Watt power inverters.

Explanation of the picture above is as follows, electricity from PLN that will be used to supply loads is put into the control circuit terminals before being used to supply loads, electricity from a 2000-Watt power inverter that will be used to supply the load is inserted into the control circuit terminal first before being used to supply the load. The control circuit is used to control electricity from a source between PLN and the power inverter that will be used to supply the load, AC voltmeter is used to determine the voltage generated by PLN and the voltage on the power inverter, DC voltmeter is used to determine the voltage generated by a 12 Volt DC battery, ammeters are used to measure the magnitude of the electric current flowing at the load. The indicator light is used to find out the electricity supply of the PLN and the power inverter is ready, the indicator light is used to determine the electricity supply of PLN and the power inverter has flowed to the load. Indicator lights are used to determine the electricity from which source is supplying the load. The operator is in charge of setting the duration of the transfer of the power source and arranging for manual or automatic operation

\section{RESULTS AND DISCUSSION}

2.1 The test results of automatic transfer switch manually

Manual testing is done by positioning the selector switch in the manual position. This test is carried out to determine the work of manual operations on automatic transfer switch devices.

The automatic transfer switch panel load testing procedure for load from the PLN power source to the power source inverter under manual operating conditions is as follows:

When the PLN power source is dead or disconnected, the things that must be done on the testing device are

1) Position the selector in the automatic transfer switch in the manual position (this condition has indicated that the PLN supply is ready)

2) Pressing the push button on PLN on the automatic transfer switch panel so that indicates that the PLN electricity supply is on for the load.

3) Turn off or revoke the electricity supply PLN (as if the source of PLN experienced blackouts).

4) Press the push button on the power inverter so that it indicates that the power inverter is on for the load.

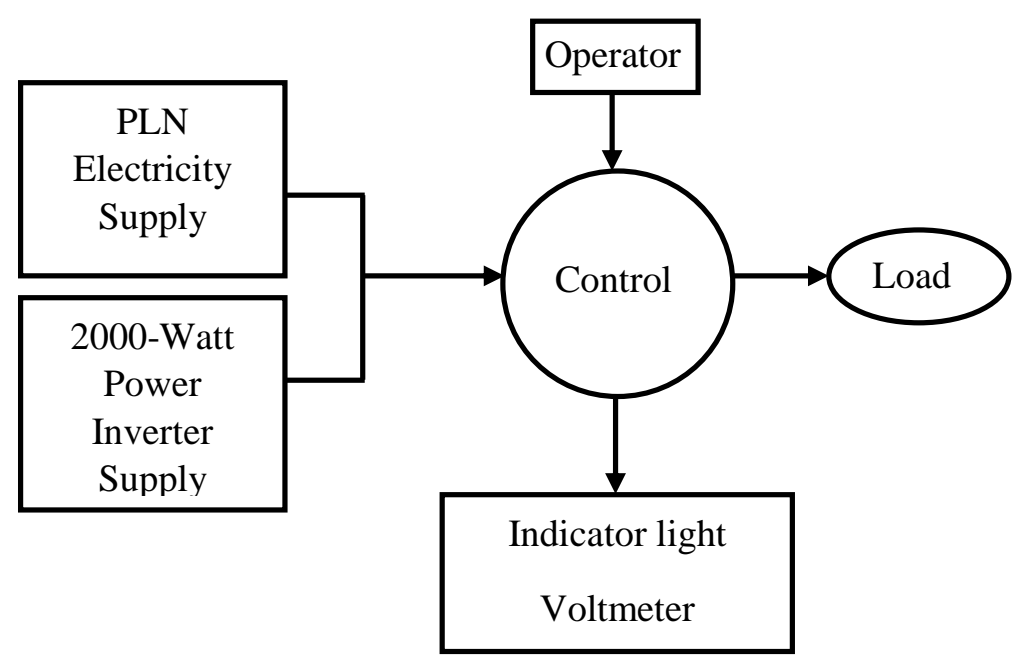

Figure 1. Automatic transfer switch operation on PLN electricity and power inverters 
5) Reconnecting the PLN electricity supply (indicating the main PLN supply is back to normal) then press the off power inverter button then the supply from the power inverter will turn off and press the push button on PLN.

The above procedure is carried out on the instrument testing carried out, and the resource condition data obtained on the panel and indicator lights are as follows in Table 1.

Based on the test data it can be concluded that the automatic transfer switch that has been assembled has functioned well in manual operation. The main power source connection components and the constituent control of the automatic transfer switch can be concluded to work in accordance with their respective functions because the results of the data indicate the indicator lights turn on according to the desired conditions in the planning. With the above data, it can also be concluded that the wirring that is done is in accordance with the design drawings made, so that the automatic transfer switch is declared ready to be installed on the system. However, if when carrying out the procedure above, the automatic transfer switch does not work in accordance with

Table 1. Test conditions for automatic transfer switches

\begin{tabular}{|c|c|c|c|c|}
\hline Testing No. & $\begin{array}{l}\text { Condition of PLN supply } \\
\text { and inverter power } \\
\text { supply and push button } \\
\text { position on the automatic } \\
\text { transfer switch panel }\end{array}$ & $\begin{array}{c}\text { PLN } \\
\text { operation } \\
\text { indicator } \\
\text { lights }\end{array}$ & $\begin{array}{c}\text { Power } \\
\text { inverter } \\
\text { operation } \\
\text { indicator } \\
\text { lights }\end{array}$ & $\begin{array}{l}\text { Load } \\
\text { indicator } \\
\text { lights }\end{array}$ \\
\hline \multirow[t]{3}{*}{1} & $\begin{array}{l}\text { The PLN supply is } \\
\text { connected to the load, the } \\
\text { inverter power supply } \\
\text { turns off / on the PLN } \\
\text { button is pressed }\end{array}$ & on & off & on \\
\hline & $\begin{array}{l}\text { The PLN supply and the } \\
\text { inverter power supply are } \\
\text { disconnected, press the } \\
\text { PLN off button }\end{array}$ & off & off & off \\
\hline & $\begin{array}{l}\text { The PLN supply is } \\
\text { disconnected and the } \\
\text { inverter power supply is } \\
\text { connected to the load / } \\
\text { button on the inverter } \\
\text { power is pressed }\end{array}$ & off & on & on \\
\hline \multirow[t]{3}{*}{2} & $\begin{array}{l}\text { The PLN supply is } \\
\text { connected to the load, the } \\
\text { inverter power supply } \\
\text { turns off / on the PLN } \\
\text { button is pressed }\end{array}$ & on & off & on \\
\hline & $\begin{array}{l}\text { The PLN supply and the } \\
\text { inverter power supply are } \\
\text { disconnected, press the } \\
\text { PLN off button }\end{array}$ & off & off & off \\
\hline & $\begin{array}{l}\text { The PLN supply is } \\
\text { disconnected and the } \\
\text { inverter power supply is } \\
\text { connected to the load / } \\
\text { button on the inverter } \\
\text { power is pressed }\end{array}$ & off & on & on \\
\hline
\end{tabular}


the function that has been designed, then the procedure will be terminated to check the components that are not working as expected or to check the circuit (wirring).

\subsection{Automatic Transfer Switch Test Results Automatically}

Automatic Operation Test that is to test the process of transferring the load from the main supply (PLN) to the backup supply (power inverter) automatically if the source from PLN experiences a blackout without pressing any buttons so that the automatic transfer switch performs the transfer of the load from the PLN electricity to the power inverter. When this automatic operation is interrupted by the control system, the system is immediately operated manually. This operation is carried out by positioning the selector in the auto position. This test is carried out to determine the performance of the automatic operation on the automatic transfer switch.

The automatic transfer switch panel load testing procedure for the load from the PLN power source to the inverter power source under automatic operating conditions is as follows:

1) Position the selector in the automatic transfer switch panel in the auto position (this condition has indicated that the PLN supply is on for the load)

2) Turn off or revoke the electricity supply of PLN (as if the source of PLN experienced blackouts).

3) The condition of the power inverter is ready after that there is an automatic transfer from the PLN power supply to the power inverter supply, the automatic transfer process is successful.

4) Reconnecting PLN electricity supply (indicating PLN electricity supply is back to normal). Then the automatic transfer process takes place from the inverter power supply to the PLN electricity supply so that the automatic transfer switch can work as expected.

The above procedure is carried out on the instrument testing carried out, and the resource condition data obtained on the panel and indicator lights are as follows Table 2.

Based on the data and the smooth implementation of the procedure above, it can be

Table 2. Test conditions for automatic transfer switches automatically

\begin{tabular}{|c|c|c|c|c|}
\hline Testing No. & $\begin{array}{c}\text { Condition of PLN } \\
\text { supply and power } \\
\text { inverter supply on } \\
\text { the automatic } \\
\text { transfer switch } \\
\text { panel }\end{array}$ & $\begin{array}{c}\text { PLN } \\
\text { operation } \\
\text { indicator } \\
\text { lights }\end{array}$ & $\begin{array}{c}\text { Power inverter } \\
\text { operation } \\
\text { indicator lights }\end{array}$ & $\begin{array}{c}\text { Load } \\
\text { indicator } \\
\text { lights }\end{array}$ \\
\hline 1 & $\begin{array}{l}\text { The PLN supply is } \\
\text { connected then the } \\
\text { inverter power } \\
\text { supply is off }\end{array}$ & on & off & on \\
\cline { 2 - 5 } & $\begin{array}{l}\text { PLN supply is off } \\
\text { then the inverter } \\
\text { power supply is on }\end{array}$ & $\begin{array}{l}\text { off } \\
\text { The PLN supply is } \\
\text { connected then the } \\
\text { inverter power } \\
\text { supply is off }\end{array}$ & on & off \\
\cline { 2 - 5 } & $\begin{array}{l}\text { PLN supply is off } \\
\text { then the inverter } \\
\text { power supply is on }\end{array}$ & off & on & on \\
\hline
\end{tabular}


concluded that the automatic transfer switch that was designed and built has functioned well in automatic operation, because the indicator light is on in accordance with the work of the installed components. So that it can be stated that the automatic switch system tested has operated according to its function, namely to control the automatic transfer switch panel in fully automatic operation. The main power supply connection components and control equipment on the automatic transfer switch can also be concluded to work in accordance with their respective functions and the automatic circuit that is done is in accordance with the design drawings made.

\subsection{Automatic Transfer Switch Test Results Automatically}

The results of making automatic transfer switch panels on PLN electricity and 2000 watt power inverters are automatic systems that supply electricity supply operation of PLN and 2000 watt power inverters, where in an emergency with a magnetic contactor base with the help of a backup power source of 2000 watts this inverter supports two transfer operations or load transfer that is manually and automatically.

In designing and assembling an automatic transfer switch panel that has an automatic function, it takes control components and main power supply components. The control components used in the automatic transfer switch panel are timers, relays, push buttons, selector. While the main power source components used in the automatic transfer switch panel as a result of this design are magnetic contactors, MCB, and measuring devices in the form of ammeters and voltmeters and indicator lights as an indication of PLN electricity and power inverters are ready.

The main function when automatically operating the automatic transfer switch panel as the main control of emergency power is a control circuit system that monitors and controls the main PLN power source, if the PLN electricity is interrupted, this circuit will give an order to the 2000 watt power inverter to carry out operations and monitor and controlling a 2000 watt backup power inverter. The control circuit on this automatic transfer switch device only operates at the time of supply of a 2000 watt power inverter, so that if there is a failure in operation at the time of supply of a 2000 watt power inverter, then the operation when supplying the 2000 watt power inverter can be done using manual system by moving the selector to the new manual position that we press the push button on the power inverter. In Figure 2 below illustrates the automatic transfer switch panel device front view of the design results.

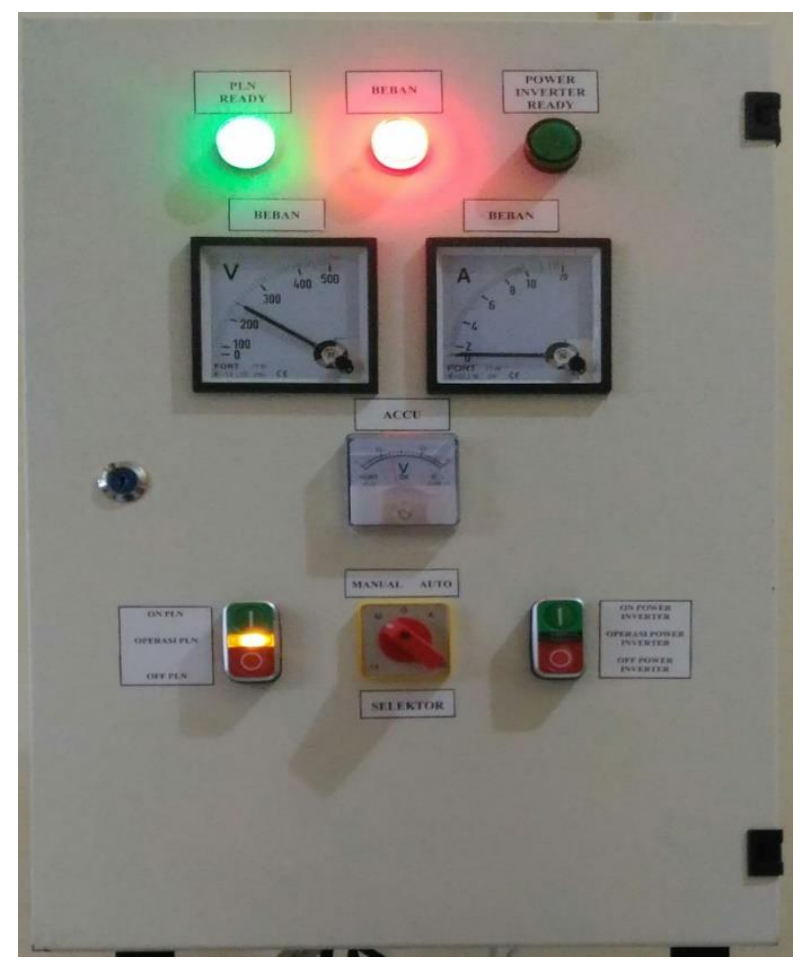

Figure 2. Automatic transfer switch operation on PLN electricity and power inverters

In Figure 3 illustrates the automatic transfer switch panel device looks the inside of the design results. The way the automatic transfer switch power inverter works is actually the same as a manual power inverter but there are some additions or tools that must be available to support a manual power inverter to be an automatic transfer switch. In this automatic transfer switch panel, the backup source of the power inverter is equipped with a 12 Volt DC battery as a power source to the power inverter where the battery supplies 12-volt DC power to the power inverter when the power from the PLN is cut off. In the power inverter itself as a backup power source is also equipped with a 12 Volt DC battery charger that operates automatically, when the power from the 12 Volt 


\section{BEST}

DC battery is reduced then this battery charger automatically fills up its power.

With the automatic operation of the automatic transfer switch panel, it is designed that the time difference from when PLN dies with the life of the power inverter can be adjusted using a timer. Of course, using the shortest possible time. But in testing this automatic transfer switch device has been set for 3 seconds. The automatic transfer switch panel on the PLN electricity and power inverter as a result of this design is supplied from a backup source of power inverter with a power capacity of 2000 Watt with a voltage of 220 Volts. This panel design is adjusted so that it can be used in household scale and small-scale commercial buildings.

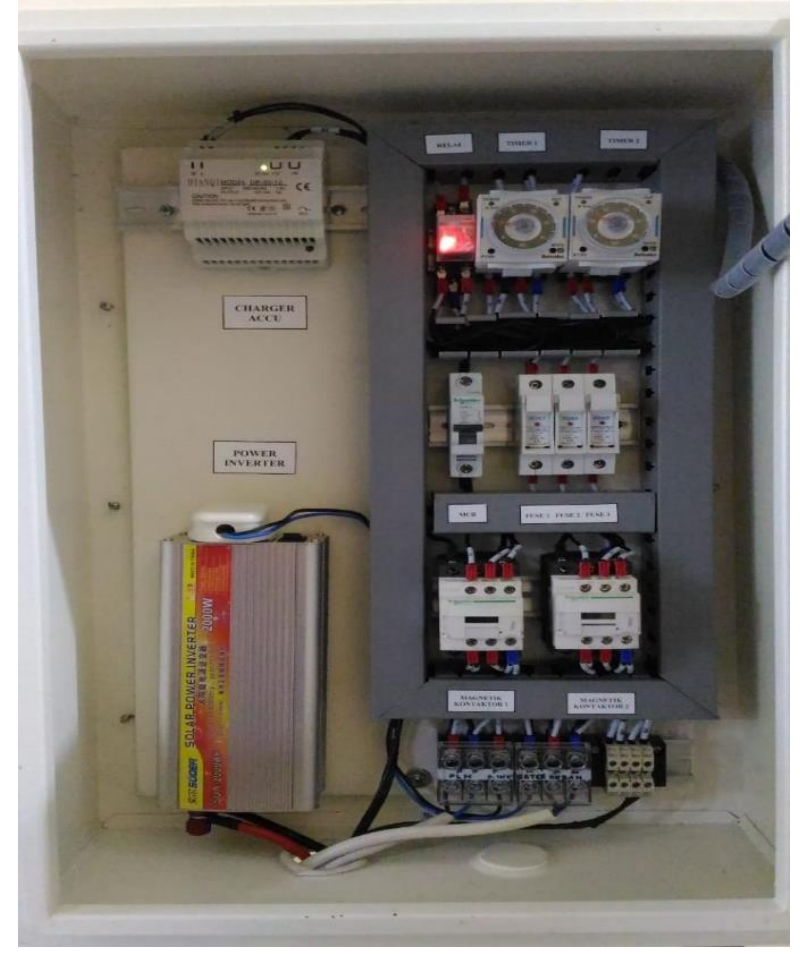

Figure 3. The automatic transfer switch panel device appears inside the panel

In Figure 4 illustrates the automatic transfer switch panel device the inside looks at the design panel door part. In this section there is the back side of the measuring instrument, namely ammeters and voltmeters, manual and automatic operation selector, also indicator lights which consist of PLN ready indicator lights, power inverter ready, loads, PLN operations and power inverter operations.

Next in Figure 5 illustrates the automatic transfer switch panel device during testing where the PLN electricity supply circuit has been connected to the household PHB MCB. Equipped with measuring devices, namely ammeters and voltmeters, manual and automatic operation selector, also indicator lights consisting of PLN ready indicator lights, power inverter ready, loads, PLN operations and power inverter operations.

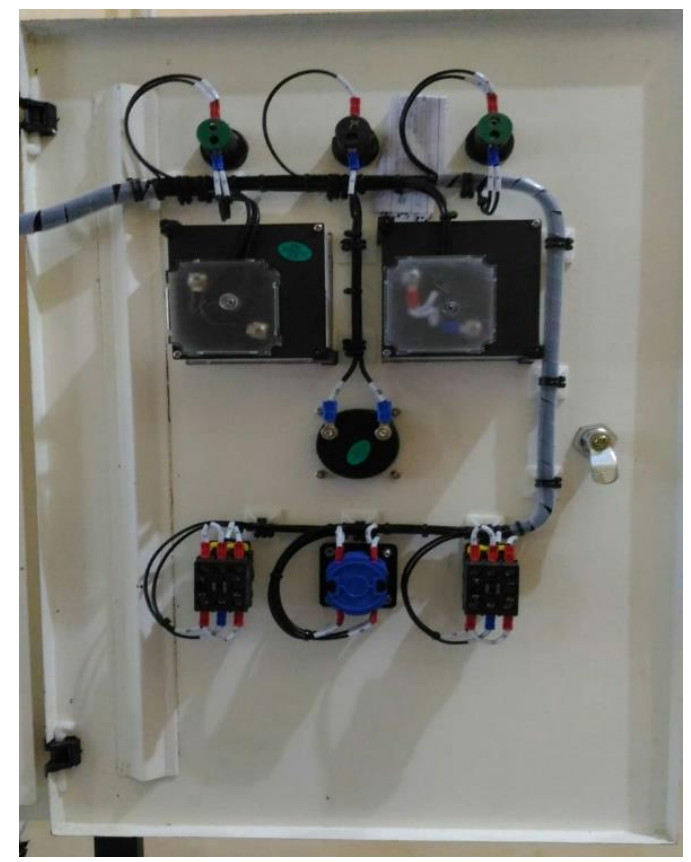

Figure 4. The inside door panel automatic transfer switch appears on the door panel

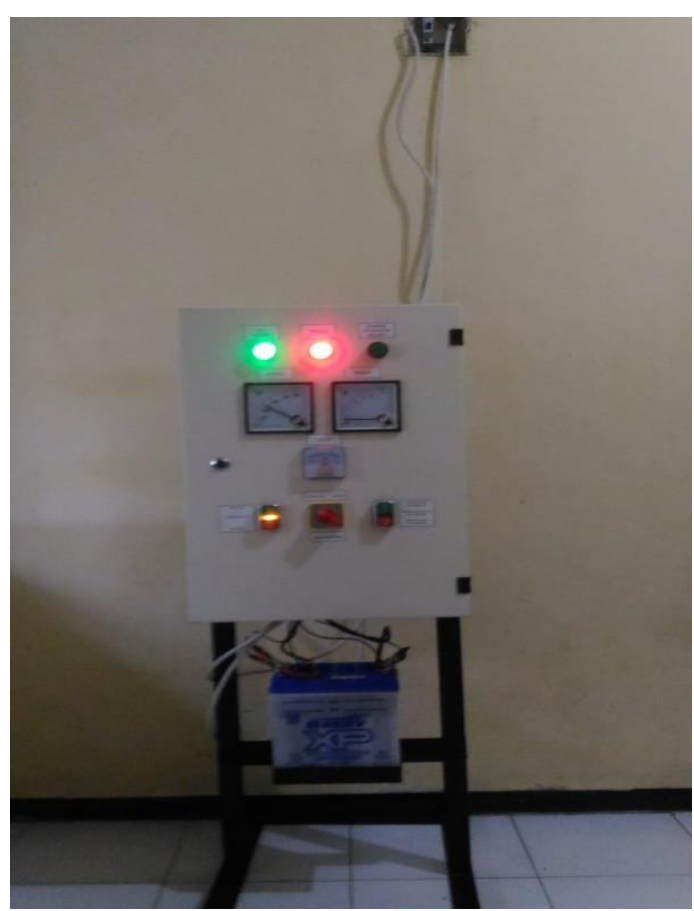

Figure 5. The automatic transfer switch panel appears to be perfect when testing 


\section{CONCLUSION}

Based on the results of making automatic transfer switch panels on pln electricity and 2000 watt power inverters, several conclusions can be made.

1. Automatic transfer switch panel device that is made can operate properly and in accordance with the plan. Based on the results of testing the function of the automatic transfer switch panel device by operating manually and automatically.

2. Magnetic contactors used for PLN electricity supply and power inverters are magnetic Schneider brand contactors with a capacity of $32 \mathrm{~A}$, and are sufficient for the distribution process to the load, for the $2200 \mathrm{VA}$ power supply and 2000 watt power inverter.

3. When there is a power outage, there is a time delay of 3 seconds before the power inverter supplies the electric power. This aims to keep the components from being damaged if at times the PLN electricity goes out for a moment.

\section{ACKNOWLEDGMENT}

I thank to PGRI Adi Buana University Surabaya Faculty of Industrial Technology especially the Electrical Engineering study program, which has provided laboratory facilities for the completion of writing this article.

\section{REFERENCE}

[1] Alrich, Walter N. 1985. Industrial Motor Kontrol. New York : Delmar Publisher INC

[2] Enggar T. Santosa (2011), "Rancangan Dasar Sistem Automatic Main Failure Dan Automatic Transfer Switch Untuk Ruang Pertemuan Gedung 71"Jurnal. Tangerang ; Pusat Reksa Perangkat Nuklir.

[3] Harten, Van P \& Setiawan E. 1985. Instalasi Arus Kuat 3. Bandung : Bina Cipta

[4] Herman, Stephen L. \& Alrich, Walter N. 1985. Industrial Motor Control. New York : Dalmar Publisher INC

[5] Rochman, Sagita, and Budi Prijo Sembodo. "Rancang Bangun Alat Kontrol Pengisian Aki Untuk Mobil Listrik Menggunakan Energi Sel Surya Dengan Metode Sequensial." WAKTU 12.2 (2014): 61-66.
[6] Indhana Sudiharto,ST,MT, dkk, (2011), "Rancang Bangun Sistem Automatic Transfer Switch (ATS) dan Automatic Main Failure (AMF) PLN - Genset Berbasis Plc Dilengkapi Dengan Monitoring" Jurnal. Surabaya ; Jurusan Teknik Elektro Industri PENS-ITS.

[7] Panitia Penyempurnaan PUIL, 2000, Persyaratan Umum Instalasi Listrik Indonesia 2000 (PUIL). Jakarta : PT. Pradya Paramita

[8] Petruzella, Frank D. (2001). Industrial Electronics. (Alih Bahasa Oleh Sumanto) Bandung : Andi

[9] Sudiharto, Indhana dkk, Rancang Bangun Sistem Automatic Transfer Switch (ATS) dan Automatic Main Failure (AMF) PLN-Genset Berbasis PLC Dilengkapi Dengan Monitoring, Surabaya, Jurnal Jurusan Teknik Elektro Industri PENS-ITS, 2011.

[10] Suganda Imam. 2000. Instalasi Listrik Untuk Rumah. Bandung : Yayasan Usaha Penunjang Tenaga Listrik 